\title{
Cross-influence between Language and Culture: Pause Structure as Proof of Cultural Difference in the Same Language
}

\author{
Irena Marković and Ivana Škevin \\ University of Zadar \\ imarkov@unizd.hr \\ iskevin@unizd.hr
}

Raziskave o različnih strukturah za premore v spontanem govoru v različnih jezikih so pokazale, da so le-te kulturno pogojene. Kljub temu analiza različnih tipov premora znotraj istega jezika v dveh različnih regijah kažejo, kako jezik sam po sebi ne vpliva na kulturno komponento pogovora (čeprav se kultura prenaša prek jezika). Predstavljena raziskava temelji na posnetkih spontanih hrvaških govorcev iz dveh različnih regij (Istra in Dalmacija). Obe skupini naj bi imeli podobno jezikovno, zgodovinsko in kulturno ozadje z minimalno stopnjo razlikovanja.

Ključne besede: premori, menjavanje pogovornih vlog, pogovorni stil, prekrivanje, Pula, Zadar

La ricerca sulle diverse forme di pausa (utilizzate nella produzione linguistica) in diverse lingue si rivela essere una questione di cultura. Tuttavia, i diversi tipi di pause all' interno della stessa lingua in due regioni mostrano come la lingua stessa non influenzi veramente la cultura del discorso (anche se la cultura viene trasmessa attraverso il linguaggio). La ricerca è basata su registrazioni del discorso spontaneo di parlanti croati di due diverse regioni (Istria e Dalmazia). Si ritiene che entrambi i gruppi abbiano analoghi ambiti linguistici, storici e tradizionali con un livello minimo di differenziazione.

Parole chiave: pause, il turn-taking, stile conversazionale, sovrapposizioni, Pola, Zara.

$\mathrm{T}$ he idea for this study was inspired by different kinds of perception or stereotypes attributed to conversational dynamics of groups of speakers coming from two different Croatian towns - Zadar and Pula. There are different languages with very similar cultures, just as there are similar languages with different cultures. Both presumptions can confirm how culture and language are related, but they can also show where the language influence ends and where the culture influence begins. For example, we can presume the similarity in cultures of Germanic family of languages, even though their languages differ. A more difficult task seems to be the mental acceptance that the same languages can have very different cultures. This problem is always connected with the idea of nation as a separate and distinctive unit of culture and most of the studies use language as the most relevant cultural element. In this paper we will try to show how language can influence culture, but also how the same language (even dialect) can have different cultural cues. Somehow, in literature, the paralinguistic cues are usually seen as a cultural or personal matter. In this manner we will try to understand which part of paralinguistic cues is transmitted purely through language, and which part is defined by culture.

\section{Turn-taking (culture and language)}

Turn-taking as a fundamental part of conversation and generally linguistic performance has been studied by many different disciplines starting from anthropology, psycholinguistics, eth- 
nology, and ethnography, to being studied as a purely linguistic part of performance. Each of these disciplines conducted their research depending on the field of interest and the goal or aim they wanted to achieve. In this respect anthropologists try to confirm that languages and cultures are ultimately built around each other. Intercultural discourse analysts and sociolinguists try to understand negative stereotypes and misunderstandings in intercultural communication as differences in cultural perceptions, etc. However, common to all these disciplines is one simple question underlined from the beginning. Is turn-taking (as a paralinguistic unit) universal to all cultures and languages, or are there cultural and linguistic variations? If there are, are they culturally or linguistically motivated?

\section{Cultural diversity in turn-taking}

Different disciplines present plenty of literature for both claims or points of views. Nordic cultures are said to produce long delays in communication between one turn and the next. In New York Jewish conversation there is a report on "fast rate of turn-taking", while the inhabitants of an Antiguan village tend to have an "anarchic" conversation, where two or more voices easily go on at the same time. ${ }^{3}$ In that respect the Italians seem to be more tolerant to overlap, ${ }^{4}$ while the Japanese are said to leave longer gaps of silence before responding. ${ }^{5}$ Before we proceed, we must underline that there is no comparative quantita-

I Karl Sajavaara and Jaakko Lehtonen, "The silent Finn revisited," in Silence: interdisciplinary perspectives, ed. A. Jaworski (Berlin, NY: Mouton de Gruyter, 1997).

2 Deborah Tannen, "Interpreting Interruption in Conversation," 25th Annual Regional Meeting of the Chicago Linguistic Society (1989), 267-287.

3 Karl Reisman, "Contrapuntal conversations in an Antiguan village," in Exploration in the Ethnography of Speaking, eds. R. Bauman and J. Sherzer (Cambridge: Cambridge University Press, 1974).

$4 \quad$ Alessia Agliati, Antonietta Vescovo and Luigi Anolli. "Conversation patterns in Icelandic and Italian people: Similarities and differences in Rhythm and Accommodation," in The hidden structure of interaction: From neurons to culture patterns, eds. L. Anolli, S. Duncan, M.S. Manguson, G. Riva (Amsterdam: IOS Press, 2005).

5 Gudykunst, William B. and Tsukasa Nishida, Bridging Japanese/ North American Differences (Thousand Oaks: Sage Publications, 1994). tive research that proves these findings as they are mainly reported by ethnography and anthropology. What is also important for our study is that these differences in turn-taking (generally presumed) are language related, mainly because the paralinguistic aspects of languages are strongly related to culture. That is why the cultural diversity should be studied separately from language. This is possible by analysing turn-takings in groups of speakers of different regions but of the same language.

\section{Universal hypothesis in turn-taking}

In contrast to the previous claims on diversity, there are many arguments that confirm a universal system for turn-taking. According to Schegloff, 6 this system should be based on the norm "minimal-gap minimal-overlap". Therefore, there should be a functional basis for turns to be immediately adjacent (rather than overlapping or overly separated). ${ }^{7}$ The lack of systematic research regarding the cross-linguistic comparison has been resolved with the study of Stivers et al. ${ }^{8}$ The study compared speakers of ten different languages (using the multivariate analysis of four types of question-answer). For example, the mean time of turn transition for responses coded as answers versus responses coded as non-answer responses, or for questions coded with speakers' gaze versus questions coded without speakers' gaze, etc. It confirmed that turn-taking system in those languages occurs generally with minimal delay or overlap and suggested that the language structure does not explain the variance they have observed, for example slower responses for languages that use sentence final markers.

They suggest that the differences involve a different cultural "calibration" of delay, thus constituting minor variation in the local implementation of a universal underlying turn-tak-

\footnotetext{
6 Emanuel A. Schegloff, "Sequencing in Conversational Openings," American Anthropologist, 70 (1968): 1075-1095.

7 Tanya Stivers et al, "Universals and cultural variation in turn taking in conversation," Proceedings of the National Academy of Sciences, 106 (26), (2009): 10587-10592.

8 Stivers et al, "Universals and cultural variation in turn taking in conversation."
} 
ing system. The confirmation of the universal turn-taking hypothesis leaves us with two problems. How come there are still quite different perceptions of turn-taking variations in different languages and cultures? Is it possible that the reasons for these variations can be found in visual signs and other types of non verbal behaviour that always accompany conversation? If that is the case, is it possible that more gestures and body talk result in more overlapping and that there are longer pauses in cultures with less body talk?

\section{Turn-taking differences within the same}

\section{language}

To distance ourselves from different culture-language-nation similarities or variations we first have to look into the studies that have been done on turn-taking in the same language. In sociolinguistics the best examples of such studies are presented by Tannen ${ }^{9}$ who compared East European Jewish speakers from New York and Christians from California. Zimmerman and West ${ }^{\text {1० }}$ (1983, 1975), Eakins and Eakins (1976), ${ }^{11}$ Esposito $(1979)^{12}$ describe different performance styles in the same language speaking communities based on gender, while Lein and Brenneis ${ }^{\mathrm{I3}}$ and Kochman $^{14}$ base their studies on different ethnic backgrounds (black and white English speakers). Tannen described the first group as speakers with high-involvement style and the second as high-considerateness style (even though in her

9 Tannen, "Interpreting Interruption in Conversation," 267-287.

io Candace West and Don H. Zimmerman, "Gender, language, and discourse," Handbook of discourse analysis, 4 (1985):103-124; Candace West and Don H. Zimmerman, "Sex roles, interruptions and silences in conversation," in Language and Sex: Difference and dominance, eds. B. Thorne and N. Henley (Newbury House: Rowley, Mass, 1975).

I Barbara Eakins and Gene Eakins, "Verbal Turn-Taking and Exchanges in Faculty Dialogue," in The Sociology of the Languages of American Women, eds. Betty Lou Dubois and Isabel Crouch (San Antonio, TX: Trinity University Press, 1976), 53-62.

I2 Anita Esposito, "Sex differences in children conversation," Language and Speech 22 (1979), 213-220.

13 Laura Lein and Donald Brenneis, »Children's Disputes in Three Speech Communities, « Language in Society 7 (3) (1978): 299-323.

I4 Thomas Kochman, Black and White styles in conflict (Chicago: University of Chicago press, 1981). later paper she tries to distance herself from such generalizations and labelling). She talks about pauses and overlaps as a part of different conversational styles, which are learned growing up, as one learns to talk. According to her our styles are influenced by the social groupings that determine whom we hear and talk to growing up - all the ethnic, regional, and class distinctions that have so many reverberations in society. ${ }^{15}$ There are two problems to be considered: personal conversational style and different ethnic and religious background.

Conversational style is usually perceived through different manners of a person's language use that depends on different sociolinguistic elements (informal or formal speech, close friends or unknown person, age of the listener, topic of conversation, involvement, personal style). But it is always ascribed to one person only. Can we define different groups of speakers in the same way? The second problem is the ethnic and religious background that the author is underlining in defining the cultural variation of the same language speaking community without considering different region-town provenience. This element automatically assumes different historical and traditional backgrounds, which emphasizes the cultural influence on their difference in overlapping or pausing. However, the historical and traditional backgrounds should be the same for our study. And finally, unlike Tannen's study, ${ }^{16}$ we are not interested in finding out if speakers with longer pauses are seen as slow, or if speakers with more overlaps are perceived as more dominant, aggressive or with "no manners". Therefore, we will not be looking at interruptions (as negative overlaps) or pauses (as perfectly timed conversation). Primarily, our aim is to find out whether there are differences in these two regions, and, if there are, what has caused them notwithstanding their similar traditional and historical backgrounds.

I5 Tannen, "Interpreting Interruption in Conversation," 276-277.

I6 Tannen, "Interpreting Interruption in Conversation," 276-277. 


\section{Method of research}

There are plenty of examples of methodological backgrounds described in recent literature regarding discourse analysis, specifically conversation analysis ${ }^{17}$ and interactional sociolinguistics. ${ }^{18}$ As they are all interdisciplinary in nature, most of them use similar methodologies, usually defined by discourse analysis, trying to analyze the most spontaneous speech and obtain less contaminated results. Even if their methodologies slightly differ (the first using the interpretation of the speaker as grounds for analysis and the second not assuming that the researcher needs to consult the participants in conversation or members of their speech community), the method of research will generally follow their bases. Many studies use telephone recorded conversation (which obviously shows a different strategy or style of talking due to the lack of nonverbal signs). However, we will record spontaneous, face to face conversation (occurring between two or more people) and all the data will be drawn exclusively from talk-in-interaction. The next step will be the analysis of the structural linguistic specifics of the performance groups followed by the analysis of paralinguistic (contextual) cues, specifically pauses and overlaps.

For the purpose of structural analysis we will use traditional methods when necessary. In order to avoid all possible variations that could be caused by different situational cues (age, gender, informal or formal conversation, less or more involvement, educational background, relaxed or serious topic) we recorded spontaneous conversations taking into account all of the above.

17 Harvey Sacks, Emanuel A. Schegloff and Gail Jefferson, "A simplest systematics for the organization of turn-taking for conversation," Language, 50 (1974): 696-735; Maxwell J. Atkinson and John Heritage, Structures of Social Action: Studies in conversation Analysis (Cambridge: Cambridge University Press, 1984); Stivers et al, "Universals and cultural variation in turn taking in conversation."

I8 John J. Gumperz, Discourse Strategies. Studies in Interactional Sociolinguistics I (Cambridge: Cambridge University Press, 1982); Deborah Tannen, "Language and culture," in An Introduction to Language and Linguistics, eds. R.W. Fasold and J.C. Linton (Cambridge: Cambridge University Press, 2006), 343-372.

\section{Linguistic, historical and ethnic backgrounds of Pula and Zadar}

In order to understand the present cultural and linguistic situation of the two cities, we have to take into consideration their linguistic, ethnic and cultural history. Over the centuries Pula and Zadar have mainly trodden the identical linguistic, cultural and historical paths even though, due to differences in geographical position and political importance, their paths diverged at times. They share the same ancient linguistic history and cultural unity created on the Adriatic coast by the Romans somewhere in the middle of the 2 nd century BC. Thereafter their histories grew apart only to be reunited at the end of the 6th century when they shared the destiny of Slavic invasions. The invasions not only brought the Slavic language but also caused linguistic fragmentation and stratification.19 During the creation of Slavic settlements in both areas, while Pula was firstly under the Lombards' and afterwards mostly under the Franks' reign, $\mathrm{Za}^{\circ}$ dar in Dalmatia adopted the Croatian spirit, culture and language especially during and after the formation of the Croatian Kingdom in 925. In Zadar, this was the period of the most intense development of Dalmatian - Romance language from vulgar (spoken) Latin mainly in the city centres and in Pula the same was happening with the Istriot language. While the Croatians were very influential in Zadar, bearing important titles, in Pula and in other parts of Istria they were mostly farmers. In this aura of the rise of the feudal system in Istria and of prosperous development in Dalmatia both cities were facing the near arrival of Venice. Although Venetian linguistic and cultural influence started in the 9 th century and ran parallel with the rise of Dalmatian and Istriot Romance languages, Pula officially became a part of the Republic of Venice only in $133 \mathrm{I}$ and Zadar in 1409 when Ladislaus of Naples sold his rights to Dalmatia for a paltry sum of 100000 ducats. Venetian economical

19 Michael Metzeltin, "La Dalmazia e l'Istria," in L'italiano nelle regioni. Lingua nazionale e identità regionali, ed F.Bruni (Torino: UTET, 1992), 316-335. 
and political aims not only defined the development of both cities in the next few centuries, but also brought the Venetian language whose traces are visible even today.

During the period of Venetian government Pula was continuously attacked by Genoese and Croatian-Hungarian armies on one side and by numerous epidemics of plague, malaria and typhoid on the other. Only its geographical position and the importance of its harbour saved it from a complete decline. Zadar was also going through rough times, especially in the 16 th and 17 th centuries when, weakened by constant Turkish attacks and frequent Venetian-Turkish wars, its existence was balancing between two political tendencies: the Venetian centralism and Turkish imperialism. This was also a crucial historical point for the beginning of diversification of Čakavian dialects of Pula and Zadar, the latter being characterised by numerous Turkish lexical elements. With the fall of Venice in 1797, both cities first passed to Austrian (1797-1805), then French (Napoleon, 1806-1813), and then again Austrian rule (I8I4-1918). From the end of World War I, Zadar and Pula again shared the same destiny: both were excluded from the Kingdom of Serbs, Croats and Slovenes and remained Italian provinces until 1947 when they both joined the rest of Yugoslavia. ${ }^{20}$ The period between the two great wars was economically and politically difficult. From the cultural and linguistic point of view, the Italian influence penetrated deeply into the cities and vividly and directly endured throughout the first half of the 2oth century. Although the historical facts seem to prove differently, the Italian influence in Pula and in Zadar had different impacts and different directions leaving Pula today with many bilingual Italian-Croatian speakers and Zadar with mainly monolingual Croatian speakers. In 199I both became part of the new Republic of Croatia. Today, the spoken language of both cities is Croatian based on Čakavian-Ikavian dialect, whose dialectal features are fading away and be-

20 Lelija Sočanac, Hrvatsko - talijanski jezični dodiri: s rječnikom talijanizama u standardnome hrvatskom jeziku i dubrovačkoj dramskoj književnosti (Zagreb: Globus, 2004). coming more standardized. The fact which is relevant for our study is that Zadar's spoken language is getting closer to the Novoštokavian dialect and that there are only a few bilingual, mostly elderly, Italian-Croatian speakers left, while in Pula and in its surroundings the Italian community is still rather influential.

\section{Analysis}

\section{Transcripts and classification of turn-taking}

cues

The primary interests of our analysis are the turn-taking cues (pauses, latches, interruptions and overlaps) and not the semantic component of the recorded conversations. Knowing that its spoken language specificity would be partially lost in its translation in English, we decided to transcribe it in this paper only in its original Croatian version. However, the reader should be able to understand the conversational cues from the transcripts that are systematically organized and that visually and graphically follow the flow of the conversation. The conventions used in the transcript, presented in the following table, are an adaptation of the systematics for the organization of turn-taking proposed by Sacks, Schegloff and Jefferson: ${ }^{21}$

Table i Systematics for the organization of turn-taking

\begin{tabular}{|c|c|}
\hline Key & Explanation \\
\hline$=$ & Latching \\
\hline (number) & $\begin{array}{l}\text { Duration of an inter-turn pause or betwe- } \\
\text { en two turn-takings expressed in tenths of } \\
\text { seconds or in seconds. }\end{array}$ \\
\hline & $\begin{array}{l}\text { The point of interruption and the be- } \\
\text { ginning of the overlap }\end{array}$ \\
\hline$]$ & The end of the overlap \\
\hline $\begin{array}{l}\text { Sacks, } \\
\text { nizatio }\end{array}$ & $\begin{array}{l}\text { and Jefferson, "A simplest systematics for the orga- } \\
\text { taking for conversation." }\end{array}$ \\
\hline
\end{tabular}




\begin{tabular}{ll}
\multicolumn{1}{c|}{ Key } & \multicolumn{1}{c}{ Explanation } \\
\hline (explanation) & $\begin{array}{l}\text { Description of the conversational situa- } \\
\text { tion. } \\
\text { Explanation of not understandable parts of } \\
\text { the conversation. }\end{array}$ \\
\hline UPPER CASE & \begin{tabular}{l} 
Increased volume \\
\hline
\end{tabular} \\
\hline & Talk it precedes is low in volume.
\end{tabular}

A pause can be classified as an inter-turn pause (represented by a number in parentheses expressed in tenths of seconds or in seconds), a normal pause (longer than a latch but shorter than half a second, represented by a punctuation mark) and a pause between two turn-takings (longer than half a second and represented by a number in parentheses). Equals at the end of a prior and at the start of a next instance of talk are used to present that the two turn-takings are latched together. Interruptions, in the transcript presented by a square bracket opening, usually have a negative connotation ${ }^{22}$ and refer to all the vocalizations where while one subject is speaking, the other subject utters at least one word or a few syllables of a single word. The square bracket opening represents also the beginning of an overlap, which is, unlike interruption, closed with another square bracket at the end of the instance of talk that overlapped the previous one. Overlaps are in principle neutral and can end in simultaneous talk (when at least two voices vocalize more than one word at once). ${ }^{2}$

\section{Croatian speakers of Zadar}

Our recordings show a naturally occurring conversation among four female friends and work colleagues in their thirties. During their lunch break they go for a cup of coffee to a nearby coffee shop. Their conversation is very casual constantly switching from one subject to another. They start with slandering one and planning a surprise for another colleague, continue about going abroad and scholarships, having a baby and getting married and finally, after having noticed

\footnotetext{
22 Tannen, "Interpreting Interruption in Conversation," 276-277.
}

23 Tannen, "Interpreting Interruption in Conversation," 276-277. a very handsome waiter, they talk about men and about age differences in relationships and marriage. Sacs, Schegloff \& Jefferson ${ }^{24}$ in their study proposed that there must be some formal apparatus which is itself context-free, in such ways that it can be sensitive to and exhibit its sensitivity to various parameters of social reality in local context. According to them some aspects of the organization of conversation must be expected to have this context-free, context-sensitive status; for of course, conversation is a vehicle for interaction between parties with any potential identities and with any potential familiarity. Unlike the authors who consider it undesirable to have to characterize situations of particular conversations in order to investigate them, we decided to determine the conversational context in order to facilitate the interpretation of the results. The conversational "manners" of Zadar's and Pula's speakers fit into, but to a different extent, the proposed general aspects observable in any conversation. Zadar's conversational style is mostly characterized by the following statement: "Occurrences of more than one speaker at a time are common but brief," ${ }^{25}$ although the briefness they talk about is interpretable in more ways than one. Some of the instances of overlaps (from one to three or four words) that these authors identify as brief, for speakers from Zadar and especially from Pula would be considered long and identified as simultaneous talk. Zadar's recordings prove that a very large amount of turn-takings ends in overlaps, many of which continue in simultaneous talk. This is illustrated in the following examples.

\section{Example 1}

C: Još da kape nabavimo. $=$

$\mathrm{G}:=($ Singing) Sve b[i seeeke ljuuubile mornare.

M: [Što da nabavimo?]

$$
\text { Example } 2
$$

T: [Onda da i ja ovako [okrenem da bude jasno?

24 Sacks, Schegloff and Jefferson, "A simplest systematics for the organization of turn-taking for conversation," 699-700.

25 Sacks, Schegloff and Jefferson, "A simplest systematics for the organization of turn-taking for conversation," 706-708. 
G: [i onda kad vidi moj. Da], da. Ali neću ti reći koj[a je.

\section{Example 3}

$\mathrm{C}:=[$ Ma vi niste normalni!

$\mathrm{M}:=[$ Pitat ću ga ja $]=$

There are many overlaps that intrude into other speakers' turns but do not interrupt the entire sentence of the previous speaker but only the last word or its last few syllables. We define them as minimal overlaps because they, unlike interruptions, have a positive connotation and they do not cause the change of subject.

Example 4

G: = Jel je bej[be?

C: [Ne znan koja je .. ali dobro je, dobro je.. virujen va[n

$\mathrm{T}$ : [Baš je smišna ona

\section{Examples}

C: = A Kosmatović, da, da, da. Mislila san Roksan[ović.

G: [Tonka Grubelić Kosmatović. (o.2)

Tonka Kosmat[ović

T: [To je u biti idealno, idealno [prezime za mene.

G: [Oćeš zadržati prezime?] Oćeš zadržati prezime? =

It is obvious that most instances of minimal overlaps have a cooperative effect and their only function is to convey interest to the other speaker and to encourage and reinforce her.

\section{Example 6}

M: [Znaš kako san ja jučer u shopping centru. Ja iden kupiti sladoled, i tamo na šalteru, da na šalteru, na šanku stoji tamo dvadeset voda, biće ono da ne liva, on nos[i

C: [vooda? =

$\mathrm{M}:=$ Voda. $=$

$\mathrm{C}:=\mathrm{A}$ ha! $=$

$\mathrm{M}:=$ Dvadeset čaša $\operatorname{vod}[\mathrm{e}$.

$\mathrm{C}:[\mathrm{E}$ !

\section{Example 7}

M: Tako ti j[a

G: [A ha, a ha, a ha

When overlaps change the sequence of conversation and cause the change of subject, they are defined as interruptions. Even though the previous speaker did not finish her sentence or her story, and even though the intent of these interruptions does not have a very cooperative effect, but rather the obstructive one, the speakers do not report the resentment at being interrupted:

\section{Example 8}

C: Ja san jedanput došla, ali mi se činilo da san van pokvarila kavu, bila san sva ono gmmm..mm gmmmm..mmm (laughing), a Marijana došl[a

M: [Nisan ja bila=

C: =Bila si, to je jedna od rijetkih kava pa znam, a [Marijana s novinama

G: [Ne mogu vjerovati da] ja jedina držin boršu, aj sad ću viditi $=$

$\mathrm{C}:=\mathrm{Ne}$, pa stavi je, to je borša koju trebaju svi viditi. (3)

M: Jel ti se svida torba?=

G: = Super mi je (I.5), praktična je, ima puno

mjesta i dosta pretinac $[\mathrm{a}$

C: [a ona

$\mathrm{T}$ : (not understandable)

C: A roza boja unutra?=

G: = Predivna je, vražja je.

Besides overlaps and interruptions, the second most noticeable detail is that all four speakers frequently initiate turns that latch onto other speakers' turns:

\section{Example 9}

$\mathrm{C}:=\mathrm{Da}$, a kad si se ošišala. Pita te nešto.=

$\mathrm{G}:=$ Oćeš li zadržati? =

$\mathrm{T}:=\mathrm{Da} !$

The conversations accommodate a wide range of subjects and situations. These changes of subject or situations or changes of subject within a situation are marked by a noticeable de- 
crease in overlaps and increase in the number of longer pauses. When the subject of the conversation becomes serious, the speakers seem to find a refuge in longer pauses which, in comparison to all the previous overlapping seem like very long silences. In Zadar's recordings there aren't any normal pauses, the speakers either latch onto each other's turns or leave space for longer pauses between the two turn-takings (never longer than 5 seconds). The rare recurrence of either normal or longer pause increases their stylistic effect. This is noticeable either within a talk sequence of a single speaker:

\section{Example io}

$\mathrm{T}$ : = Ispušili smo, (0.2) jučer smo saznali. (0.2) Poslali su nam mail odjeba, (I.5) odjebni mail. (0.5)

Or within the sequence in which the talk shifts from one speaker to another:

\section{Example iI}

$\mathrm{T}:=$ Nije me briga, iden pravit dite ( 5$)$

The following extract shows the use of a longer pause between the turns combined with the use of a lower tone of voice while slandering another person:

\section{Example I2}

$\mathrm{C}:{ }^{\circ} \mathrm{Ne}$ mogu vjerovati $=$

$\mathrm{M}:$ = Ne obraćajte pozornost, ne slušajte, ma mislin, [ma njega slušati.

G: [Ovaj je dobar za tebe. $]=$

$\mathrm{C}:$ = Ma nisan uopće, nisan ga. (0.5). Ajme meni.

(I)

G: ${ }^{\circ}$ Počeja je u sitno ići. (3) A jadan, meni je njega baš milo. (2)

There are also cases in which one of the speakers speaks in increased volume in order to make a point or to be heard:

\section{Example I3}

C: $S$ kojom to želiš napraviti, (I.s) malog Mislavića. $=$

$\mathrm{T}:=$ Nije on mali, on je mršav, ali nije mali. $=$
G: = MA MALOG MISLAVIĆA DA NAPRAVIŠ! =

\section{Croatian speakers of Pula}

The second analysis is based on recorded conversation between two Croatian speakers from Pula. The parties involved are two female friends in their thirties having a morning coffee in a local coffee shop and chit chatting about common things, like places they went to the previous evening, people they met and superficial personal details. The organization of turn-taking in $\mathrm{Pu}$ la's case seems to follow all the general points proposed by Sacs et al.26 In most cases there is only one speaker talking at a time, even though there are brief and rare instances of overlaps. Unlike the Zadar's situation, transitions generally have no longer pauses or overlaps, even though slightly longer pauses and overlaps are also common. Most of the context situations are not fixed but vary from turn order, turn size, length of conversation, and subject of conversation to distribution of turns. They all possess turn constructional units and repair mechanisms for violation or turn-taking errors. However, there are some additional specific features like notable quantity, much higher than average, of quite long pauses between the turns (the longest lasts for Io seconds).

\section{Example I4}

S: [Vidim ja oni koji su uvijek visili u Kabahiji sad su u Skandalu (3) svi živi (2) i Kabahija prazna, tako je prošli put bilo kad sam bila vani. (5) I: I tako onda smo došli tamo, bilo mi je drago ali bila sam jako napeta, zato što smo trebali izaći u 9 i po.

It also seems common that when a long pause occurs, the person who spoke last takes the next turn of the conversation again:

\section{Example is}

S: A jadna! (s)

S: Znači to uopće nije vezano za nešto (5) fiziološki? 
If a pause of one or two seconds occurs during one speaker's talk sequence, the other speaker often interprets it as a sign of turn-taking and begins her turn (in most cases without overlapping with the first speaker):

S: A Sonja je?

I: Da e? (2) I onda počneš pričat o tome, i onda misliš (I) jebote. (I)

S: Kad ne kuže! Kad nisu to proživjeli.

However, if an overlap occurs in these situations, it does not continue with simultaneous talk, but one speaker ends her turn after one or two words:

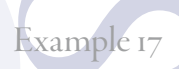

I: Inače ova jedna je iz Njemačke, živi tamo, (I) S: [A Diana?

I: [A Diana ti je tu (not understandable) ona jako posebna.

When overlaps do occur they are expressed with words like yes, and non-verbal fillers such as: $\mathrm{mm}$, aaa, oo. They have a cooperative effect and their function is an affirmation or negation of the other speaker or a confirmation of involvement in the conversation. They belong to the category of previously defined minimal overlaps and they account for more than $80 \%$ of overlaps identified in the recordings of Pula's Croatian speakers.

\section{I: Probat ć[u.}

S: [da da može.

\section{Example 19}

I: Ali izbjegavam, (2) i tako da ovaj mi je bilo malo bed, ali onda kad smo došli mi je bilo sve jedno i ful sam se opust[ila.

S: [ma da.

The remaining $20 \%$ of overlaps are individual in nature. As previously mentioned, some of them occur during a longer inter-turn pause of one of the speakers. The speaker pauses with- out making her point or finishing her thought, which by the other speaker is understood as a sign to begin her turn, then they start simultaneously and a brief overlap (of one or two simultaneous words) occurs. The overlap is ended by the second speaker who interrupted the first one during her inter-turn pause:

\section{Example 20}

I: Ful. Dobar je. (Stavim) na na ovaj (I)

S: To je baš[ tvoj?

I: [kompjuter i mogu pojačati kolko god želim= Example 2I

I: Inače ova jedna je iz Njemačke, živi tamo,(I) (I) S: [A Diana?

I: [A Diana ti je tu (not understandable) ona je jako posebna.

The others can be interpreted as a result of highly dynamic and very rhythmic turn-taking. The following example shows the increase in the turn-taking rhythm that begins with pauses, growing faster turns into latches and ends in a minimal overlap. However, as soon as the other speaker realizes the overlap, the conversation slows down again and reacquires normal pauses.

\section{Example 22}

\section{S: Aoo! (I) A di si išla? (I)}

S: U čirkolo? (I)

I: Ne.=

$\mathrm{S}:=\mathrm{Nego} ?=$

I: =Zašto u Čirkol[o?

S: [A jer je besplatni ulaz

I: Aaaa.

S: I Belfast Fud.

I: Nema veze, a da sam znala ne mogu ić sama, oni tu su svi vukli na svoju stranu.

\section{Conclusion}

This being a pilot study, we cannot generalize the confirmation of our hypothesis. A larger scale study would definitely provide a more reliable insight into the structure of Zadar's and Pula's turn-taking organization. For illustrative purposes only we bring forth the information that on the sample of a 12 minutes long con- 
versation in Pula, there are only 99 turn-takings and in Zadar there are 292. These mere numerical facts illustrate a considerable difference in their conversational dynamics. The analysis revealed that Pula's speakers converse using a considerable number of pauses, many of which are fairly long (even up to Io seconds between the turn-takings). On the contrary, Zadar's speakers converse in a highly dynamic way. According to the analysis, they almost never use neither normal nor longer pauses, and, when they do, they have a rather distinctive stylistic effect. Their turns either latch onto or intrude into other speakers' turns often continuing in simultaneous talk, whereas in Pula's case the analysis revealed a rather small percentage of overlaps, majority of which are categorized as minimal. Again, numbers speak in this favour: in Zadar, there are up to $38 \%$ of turn-takings ending in overlaps and in Pula there aren't more than Io\%. Greenwood 27 argued that a high rate of interruption is a sign of social comfort in conversation which is proven by Zadar's recordings. They also justify the stereotype that women are "noisy clucking hens," 28 that in in-group conversations they favour overlapping talk29 and that "women are more comfortable talking when there is more than one voice going at once" 30 which is revoked by the conversational style of speakers from Pula. Both analysis of Croatian conversation are confronted to those of Italian speakers that showed rather unexpected results. In comparison to Croatian speakers from Pula, the recordings of Italian speakers showed a much smaller percentage of longer pauses substituted with vocalized pauses and with emphatic expressions. Italian speakers from Pula are less tolerant towards slower conversational style and more flexible to latches, overlaps, interruptions and simultaneous talk. We came to a point where our matrix became more complex because we are not only faced with a possibility of different personal and temperamental styles of the speaker, but also with the possibility that solely language structure influences the conversational style.
On one hand, the comparison of conversational styles of different language speakers (Croatians and Italians) from the same regional, cultural and historical backgrounds can be considered as the basis of how a language can be accounted for their diversity and dynamics. On the other hand, there are two groups of Croatian speakers (from Pula and Zadar) that prove differently showing how the language structure does not influence the conversational style at all. Hence, the question is where do these differences derive from? Are they related to long historical processes of slightly diverse constructions of traditional, religious and cultural backgrounds or to more recent influences which caused present cultural diversity also reflected in speech? Or are they to be found in their different relations to tradition, ethnicity and religion? We can only suggest that some of the differences could derive from the stronger attachment to the Middle-European culture in Pula and to the Mediterranean culture in Zadar. Can we find this attachment to tradition in language?

The language analysis of Croatian conversations revealed their attachment to tradition but on different structural levels. For instance, speakers from Zadar are more inclined to use traditional-Čakavian linguistic elements (in phonetics and morphology) whereas $\mathrm{Pu}$ la's Croatian speakers are more inclined to preserving some traditional prosodic and syntactic features (which can be easily attributed to the present Italian influence in this region). Could we assume that the differences in conversational styles between Zadar and Pula are actually based on the expression of their group and individual personality interchange? Zadar's speakers are thought to be generally more playful, their everyday conversation is often characterized by a fairly specific humour, whereas in Pula those characteristics are not discernible (their humour is generally more subtle and their conversations are more moderate). A proof for our assumption can be found in the analysis of Zadar's conversations, which revealed more frequent occurrence of longer pauses when the conversation became 
serious as opposed to overlaps, latches and giggles when it was less serious. Zadar's conversational style is constantly changing dynamics, from growing louder to attenuating to a very low tone, and is very expressive in its usage of all the stylistic effects whereas Pula's style is rather constant and uniform. Taking into account the presented results and their possible causes, we are faced with a possibility of an entirely new research which could confirm or dismiss the new hypothesis. Nevertheless, in order to distance ourselves from any generalizations we leave the interpretation to our reader.

\section{Povzetek}

Raziskava je bila narejena na osnovi zvočnih zapisov hrvaških govorcev iz dveh regij (Istre in Dalmacije). Spontani govor je bil analiziran z namenom, da se predstavi možne razlike na vseh strukturnih ravneh (fonologija, prozodija, besedišče, oblikoslovje in skladnja), vendar se analiza osredotoča pretežno na rabo premorov (trajanje, prekrivanje ali prekinjanje pogovora). Delovna hipoteza predvideva, da na strukturne ravni vpliva jezik sam, medtem ko razlike v rabi premorov ne moremo razložiti na podlagi sprememb v jezikovnih strukturah, pač pa na osnovi regionalnih in kulturnih razlik. Rezultati analize zvočnih posnetkov hrvaških govorcev so bili dodatno primerjani s kontrolno skupino italijanskih govorcev iz Istre, ki so služili za potrditev ali ovržbo prej omenjene hipoteze. Primerjava v številkah kaže na bistvene razlike v pogovorni dinamiki obeh skupin. Analiza je pokazala, da govorci iz Pulja med pogovorom uporabljajo veliko stevilo premorov, mnogi izmed teh pa so dokaj dolgi. Prav nasprotno pa se govorci iz Zadra pogovarjajo veliko bolj dinamično. Raziskava kaže, da izjemno redko uporabljajo navadne ali daljše premore in, ko to počnejo, imajo le-ti razlikovalno-stilistično funkcijo. Njihovo menjavanje besede se bodisi navezuje bodisi posega $v$ sogovorčev govor in pogosto nadaljuje $s$ sočasnim govorom, medtem ko v primeru Pulja je analiza pokazala dokaj nizek procent prekrivanja, ki je v večini primerov minimalen. Po drugi strani pa primerjava med hrvaškimi govorci iz Pulja in posnetki italijanskih govorcev kaže, da je pri drugih veliko manj daljših premorov, ki jih praviloma zamenjajo vokalna mašila in poudarne fraze. Italijanski govorci iz Pulja so manj toleran- tni do počasnejšega pogovornega stila in bolj fleksibilni glede navezovanj, prekinjanja, seganja v besedo in sočasnega govora.

\section{Summary}

The research is based on recordings of spontaneous speech of Croatian speakers from two different regions (Istria and Dalmatia). The spontaneous speech has been analyzed in order to present the possible differences on all structural levels (phonology, prosody, lexis, morphosyntax) but the analysis is mainly concerned with the usage of pauses (duration, overlaps or interruptions in discourse). The hypothesis is that the structural levels are influenced by the language itself, while the differences in pause structure cannot be explained through language change, but only through regional and cultural diversification. The results of the analysis of Croatian speakers' speech recordings have additionally been compared to those of the third group - of Italian speakers from Istria, which may either prove or dismiss the above mentioned hypothesis. The numerical facts illustrate a considerable difference in conversational dynamics of the two groups. The analysis revealed that Pula's speakers converse using a considerable number of pauses, many of which are fairly long. On the contrary, Zadar's speakers converse in a highly dynamic way. According to the analysis, they almost never use neither normal nor longer pauses, and, when they do, they have a rather distinctive stylistic effect. Their turns either latch onto or intrude into other speakers' turns often continuing in simultaneous talk, whereas in Pula's case the analysis revealed a rather small percentage of overlaps, majority of which are categorized as minimal. On the other hand comparing Croatian speakers from Pula, the recordings of Italian speakers showed a much smaller percentage of longer pauses substituted with vocalized pauses and with emphatic expressions. Italian speakers from Pula are less tolerant towards slower conversational style and more flexible to latches, overlaps, interruptions and simultaneous talk.

\section{Reference}

Atkinson, Maxwell J., and John Heritage. Structures of Social Action: Studies in conversation Analysis. Cambridge: Cambridge University Press, 1984. 
Agliati, Alessia, Antonietta Vescovo, and Luigi Anolli. "Conversation patterns in Icelandic and Italian people: Similarities and differences in Rhythm and Accommodation." In The hidden structure of interaction: From neurons to culture patterns, eds. L. Anolli, S. Duncan, M.S. Manguson, G. Riva, 223-237. Amsterdam: IOS Press, 2005.

Decarli, Lauro. Origine del dialetto Veneto istriano. Trieste: Edizioni il canto del cigno,1976.

Eakins, Barbara, and Eakins, Gene. "Verbal Turn-Taking and Exchanges in Faculty Dialogue." In The Sociology of the Languages of American Women, eds. Betty Lou Dubois and Isabel Crouch, 53-62. San Antonio, TX: Trinity University Press, 1976.

Esposito, Anita. "Sex differences in children conversation." Language and Speech 22 (1979), 213-220

Greenwood, Alice. Discourse variation and social comfort: A study of topic initiation and interruption patterns in the dinner conversation of preadolescent children (unpublished doctoral dissertation). New York: City University of New York, 1989 .

Gudykunst, William B. and Tsukasa Nishida, Bridging Japanese/North American Differences Thousand Oaks: Sage Publications, 1994.

Gumperz, John J. Discourse Strategies. Studies in Interactional Sociolinguistics $I$. Cambridge: Cambridge University Press, 1982.

Kochman, Thomas. Black and White styles in conflict. Chicago: University of Chicago press, Ig8I.

Lein, Laura, and Donald Brenneis. "Children's Disputes in Three Speech Communities." Language in Society 7(3) (1978): 299-323.

Metzeltin, Michael. "La Dalmazia e l'Istria." In $L$ 'italiano nelle regioni. Lingua nazionale e identità regionali, ed F.Bruni, 316-335. Torino: UTET, Ig92.

Reisman, Karl. "Contrapuntal conversations in an Antiguan village." In Exploration in the Ethnography of Speaking, eds. R. Bauman and J. Sherzer, IIO-I24. Cambridge: Cambridge University Press, 1974.

Sacks, Harvey, Schegloff, Emanuel A., and Jefferson, Gail. "A simplest systematics for the organization of turn-taking for conversation." Language, 50 (1974): 696-735.

Sajavaara, Karl, and Lehtonen, Jaakko. "The silent Finn revisited." In Silence: interdisciplinary perspectives, ed. A. Jaworski, 263-284. Berlin, NY: Mouton de Gruyter, 1997.

Schegloff, Emanuel A. "Sequencing in Conversational Openings." American Anthropologist, 70 (1968): 1075-1095.

Sočanac, Lelija. Hrvatsko - talijanski jezični dodiri: s rječnikom talijanizama u standardnome hrvatskom jeziku i dubrovačkoj dramskoj književnosti. Zagreb: Globus, 2004.

Stivers, Tanya et al. "Universals and cultural variation in turn taking in conversation. Proceedings of the National Academy of Sciences, 106 (26), (2000): 10587-10592.

Tannen, Deborah. "Interpreting Interruption in Conversation." 25th Annual Regional Meeting of the Chicago Linguistic Society (1989), $267-287$.

Tannen, Deborah. "Language and culture." In An Introduction to Language and Linguistics, eds. R.W. Fasold and J.C. Linton, 343372. Cambridge: Cambridge University Press, 2006.

West, Candace, and Zimmerman, Don H. "Gender, language, and discourse." Handbook of discourse analysis, 4 (1985):103-I24.

Zimmerman, Don H., and West, Candace. "Sex roles, interruptions and silences in conversation." In Language and Sex: Difference and dominance, eds. B. Thorne and N. Henley, I05-I29. Newbury House: Rowley, Mass, 1975 . 